Creative Commons User License: CC BY-NC-ND

Abstracted by: EBSCOhost, Electronic Journals Service (EJS),

Google Scholar, Journal Seek, Scientific Commons,

Food and Agricultural Organization (FAO), CABI and Scopus
Journal of Agricultural Extension

Vol. 23 (2) April, 2019

ISSN(e): 24086851; ISSN(Print); 1119944X

http://journal.aesonnigeria.org

http://www.ajol.info/index.php/jae

Email: editorinchief@aesonnigeria.org

http://eoi.citefactor.org/10.11226/v23i2

\title{
Factors Influencing Participation of Cassava Farmers in Survival Farming Intervention Programme in Kogi State, Nigeria
}

https://dx.doi.org/10.4314/jae.v23i2.3

\section{Muhammed Yakubu*}

Department of Agricultural Extension and Rural Development, Federal University of Technology, Minna, Niger State. mohd.vak@futminna.edu.ng 08036576697

\section{Akpoko Joseph Gambo}

Department of Agricultural Extension and Rural Sociology, Ahmadu Bello University, Zaria, Kaduna State. Akpo56@yahoo.com 08033973686

\section{Musa Wamdzu Michael}

Department of Agricultural Extension and Rural Sociology, Ahmadu Bello University, Zaria, Kaduna State. mikemusa@yahoo.com 08068488698

\section{Ajayi Oladipo Joseph}

Department of Agricultural Extension and Rural Development, Federal University of Technology, Minna, Niger State. Pastordee2002@yahoo.com 08030754302

\section{Muhammad Haruna Usman}

Department of Agricultural Extension and Rural Development, Federal University of Technology, Minna, Niger State. Haruna.usman@futminna.edu.ng 07039699896

*Corresponding Author's E-mail and Phone: mohd.yak@futminna.edu.ng 08036576697

\section{Abstract}

This study assessed the factors influencing participation of cassava farmers in Survival Farming Intervention Programme (SFIP) in Kogi State, Nigeria. A multistage sampling procedure was used to select 180 respondents comprising of cassava grower in the study area. Primary data were collected with the aid of questionnaire complemented with interview schedule. Both descriptive (frequency count, percentages and mean) and inferential (Logit regression) statistics were used to analyse the data collected. Results revealed that the majority (72.8\%) of the respondents were within the age range of 36 - 55 years, while $94.5 \%$ the respondents were married. The majority (68.4\%) of the respondents acquired formal education, while $31.6 \%$ had no formal education. In term of access to SFIP activities, the majority (61.7\%) of the respondents were aware of SFIP, $65.6 \%$ were visited by extension agents under the programme, $73.3 \%$ were member of cooperative society and $58.3 \%$ of the respondents had access to credit as introduced under the programme. Major constraint identified by the respondents was poor market for produce (83.9\%) ranked $1^{\text {st }}$ among other constraints. Logit regression analysis shows that with Pseudo- $R^{2}$ of $0.68,68 \%$ of the variation in the participation in SFIP was explained by the independent variables in the model. Age (3.26), labour (2.88), education (2.53), land tenure (-2.60), awareness (5.45), extension contact (2.62) and planting material (2.80) were significant at $1 \%$ probability level, while marital status (2.47) and gender (-2.37) were significant at 5\% probability level and they statistically influence participation in SFIP. In conclusion, most of the respondents were aware of SFIP and benefited from its activities. It was therefore recommended that rural markets should be linked to the urban market to attract good value for cassava products thereby enhancing living standard of the farmers especially those in the rural areas. 
Creative Commons User License: CC BY-NC-ND

Abstracted by: EBSCOhost, Electronic Journals Service (EJS), Google Scholar, Journal Seek, Scientific Commons,

Food and Agricultural Organization (FAO), CABI and Scopus
Journal of Agricultural Extension

Vol. 23 (2) April, 2019

ISSN(e): 24086851; ISSN(Print); 1119944X

http://journal.aesonnigeria.org

http://www.ajol.info/index.php/jae

Email: editorinchief@aesonnigeria.org

Keywords: Cassava farmers, Intervention programme, Variables.

\section{Introduction}

The Nigeria agricultural sector has been constrained with factors such as poor rural infrastructure, poor fertilizer distributions and high cost of farm inputs that could have enhance the production capacity and contribution to national economy (Ugwu and Kanu, 2012). More so, the oil-boom era had led to neglect of agriculture resulting to importation of food items in massive scale (Adeniyi and Adeyemo, 2014) at the expense of locally produced ones because the rural farmers do not have the technological resources to compete in international market (Omorogiuwa, Zivkovic and Ademoh, 2014). This discourages the farmers from producing much because they no longer realized the needed profit from their effort.

However, to move forward, the country must increase the productivity of her agricultural sector through the provision of domestic policies and programmes, and increase in funding (Ayodele, Obafemi and Ebong, 2013). The goal of increasing food production and reducing food import has elicited many programmes and policies at the various levels of government. Therefore, in order to revamp the agricultural sector, the Federal Government of Nigeria had embarked on and implemented several agricultural policies and programmes some of which are defunct or abandoned, and some restructured, while others are still in place (Daneji, 2011; Iwuchukwu and Igbokwe, 2012). Government intervention programmes and policies, and the efforts of NonGovernmental Organizations (NGOs) in support of production, processing and marketing of cassava date back to the 1970s (Muhammed, 2015).

Some of the Government agricultural intervention programmes and policies aimed at increasing agricultural production including cassava production are; the Farm Settlement Scheme, National Accelerated Food Production Programme (NAFPP), Agricultural Development Projects (ADPs), River Basin Development Authorities (RBDAs), Operation Feed the Nation (OFN) and Green Revolution (GR). Others were institutions such as Directorate of Foods, Roads and Rural Infrastructure (DFFRI), National Seed Service (NSS), National Centre for Agricultural Mechanization (NCAM), Agricultural and Rural Management Training Institute (ARMTI), Agricultural Credit Guarantee Scheme Fund (ACGSF), Nigerian Agricultural Cooperative and Rural Development Bank (NACRDB), Nigerian Agricultural Insurance Company (NAIC), National Agricultural Land Development Authority (NALDA) and Specialized Universities for Agriculture (Muhammed, 2015). Agricultural Development Projects (ADPs) is an integrated approach which came into being as a result of the failure of special crop programmes to achieve rural development and food security objectives of government in Nigeria (Iwuchukwu and Igbokwe, 2012).

The NGOs efforts include Sustainable Agriculture and Rural Development Project (SARDP), Rural Poverty Eradication Project (RPEP), Cassava Enterprise Development Project (CEDP) and others (International Institute of Tropical Agriculture (IITA), 2014). All these programmes and policies due to one reason or the other have failed to meet the objective of self-sufficiency in food production. A number of new initiatives are also currently being implemented to increase area of cultivation, yields, processing and marketing of cassava products in the country. These include the presidential initiatives on cassava production, the National Special Programme for Food Security (NSPFS), Root and Tuber Expansion Programme (RTEP) and Rural Banking Scheme (Ugwu and Kanu, 2012). At the expiration of the Root and Tuber Expansion Programme time-frame in 2007, the Kogi State Agricultural Development Projects (KADP) formulated an intervention programme in Okehi LGA termed Survival Farming Intervention Programme (SFIP) with the aim of enhancing 
Creative Commons User License: CC BY-NC-ND

Abstracted by: EBSCOhost, Electronic Journals Service (EJS), Google Scholar, Journal Seek, Scientific Commons,

Food and Agricultural Organization (FAO), CABI and Scopus
Journal of Agricultural Extension

Vol. 23 (2) April, 2019

ISSN(e): 24086851; ISSN(Print); 1119944X

http://journal.aesonnigeria.org

http://www.ajol.info/index.php/jae

Email: editorinchief@aesonnigeria.org

cassava production, adding value to cassava products through processing and creating markets for the processed products especially "garr" which are packaged into various categories for sales, though, other finish products of cassava such as starch, flour, pellet and chips are also still under consideration. The programme was in later years expanded to include other LGAs. The SFIP major objective centred on improving cassava production through the provision of planting materials and other inputs, processing and packaging, and marketing along the value-chain approach to improve the production capacity of the cassava stakeholders and their level of living (Kogi ADP, 2014).

According to Ajani, Mgbenka and Onah (2015), research findings show that some of the reasons for failure of past government sponsored agricultural development programmes were poor policy formulation, programme inconsistency and implementation, corruption and poor target mechanism. It was against these backdrops that this study was conceived to assess factors influencing participation of cassava farmers in Survival Farming Intervention Programme (SFIP) in Kogi State and provides answers to the questions raised, hence the following objectives were formulated which are to:

- describe the socio-economic characteristics of the programme participants and nonparticipants in the study area;

- identify respondents access to SFIP activities in the study area;

- identify constraints associated with effective participation in SFIP in the study area, and

- determine the factors influencing participation of respondents in SFIP on cassava production in the study area.

\section{Methodology}

This study was conducted in Kogi State, Nigeria. The State lies between longitudes $5^{\circ} 40^{\prime} \mathrm{E}$ and $7^{\circ} 49^{\prime} \mathrm{N}$, and latitude $6^{\circ} 33^{\prime} \mathrm{E}$ and $8^{\circ} 44^{\prime} \mathrm{N}$ of the equator (Kogi ADP, 2014). The estimated land area of Kogi State is $29,833 \mathrm{~km}^{2}$ with a population of 3,278,487 (NPC, 2006). The projected population as at 2014 using $3.2 \%$ growth rate was 4,218,101. The vegetation zone of the State is Sudan Savanna experiencing dry and wet seasons with the usual harmathan period. The mean annual temperature is $32.1^{\circ} \mathrm{C}$, while the mean annual rainfall is $800 \mathrm{~mm}$. The three major ethnic groups and languages are Igala, Ebira and Okun (Kogi ADP, 2014). The people of the State are pre-dominantly farmers engaged in crop and livestock production.

A multi-stage sampling technique was used to select respondents for this study. The first stage involved the purposive sampling of three (3) Local Government Areas (Adavi, Okehi and Okene LGAs) from agricultural zone $\mathrm{C}$ because SFIP is situated in the area. The second stage was a random sampling of four (4) communities from each of the LGA making a total twelve (12) communities. The third stage was random sampling of fifteen (15) cassava farmers from each of the community to give a total of one hundred and eighty (180) respondents for this study. Data were collected with the aid of questionnaire complemented with an interview scheduled and was analyzed using both descriptive (frequency distribution count, percentages and mean) and the inferential (Logit regression) statistics.

\section{Model Specification Logit Regression Analysis}

Logit regression was used to determine the factors influencing participation of respondents in Survival Farming Intervention Programme (SFIP). The general Logit regression model is mathematically expressed as below:

$Y=\alpha+\beta_{1} X_{1}+\beta_{2} X_{2}+\beta_{3} X_{3}+\ldots .+\beta_{14} X_{14}+e$ 
Creative Commons User License: CC BY-NC-ND

Abstracted by: EBSCOhost, Electronic Journals Service (EJS), Google Scholar, Journal Seek, Scientific Commons,

Food and Agricultural Organization (FAO), CABI and Scopus
Journal of Agricultural Extension

Vol. 23 (2) April, 2019

ISSN(e): 24086851; ISSN(Print); 1119944X

http://journal.aesonnigeria.org

http://www.ajol.info/index.php/jae

Email: editorinchief@aesonnigeria.org

\section{Where;}

$\mathrm{Y}=$ Participation of Respondents in SFIP on cassava production ( $\mathrm{Yes}=1, \mathrm{No}=0$ )

$\mathrm{X}_{1}=$ Age in years

$\mathrm{X}_{2}=$ Marital status (Married $=1$, Single $=0$ )

$\mathrm{X}_{3}=$ Gender (Male $=1$, Female $=0$ )

$\mathrm{X}_{4}=$ Labour usage in man days

$\mathrm{X}_{5}=$ Educational level in years of formal schooling

$\mathrm{X}_{6}=$ Farmers experience in years of farming

$\mathrm{X}_{7}=$ House-hold size in numbers

$\mathrm{X}_{8}=$ Farm size in hectares

$\mathrm{X}_{9}=$ Land tenure $($ Owned $=1$, Not owned $=0)$

$\mathrm{X}_{10}=$ Awareness (Yes $=1$, No $=0$ )

$\mathrm{X}_{11}=$ Access to credit in Naira

$\mathrm{X}_{12}=$ Co-operative membership in years

$\mathrm{X}_{13}=$ Extension contact in number of visit

$\mathrm{X}_{14}=$ Planting material in kilogram

$\alpha=$ Constant

$\beta_{1}-\beta_{14}=$ regression coefficients

$\mathrm{e}=$ error term

\section{Results and Discussion}

\section{Socio-Economic Characteristics of Respondents}

The socio-economic variables examined were age, marital and educational status, farming experience, labour usage and household size. From Table 1, the majority (72.8\%) of the respondents were within the age range of $36-55$ years with mean age of 47 years, implying that respondents were in the most productive stage of their life. Age of an individual is expected to have direct relationship with agricultural production, especially energy demanding activities. This finding is in corroboration with Ayoade, Akintonde and Oyelere (2012) who reported that cassava farmers in their study area were mostly between $31-60$ years of age with mean age of 45 years. More so, the majority $(94.5 \%)$ of the respondents were married, while $4.4 \%$ and $1.1 \%$ were widowed and divorced respectively, implying availability of labour supply in the study area. Most farmers married for the purpose of pro-creation that will give a helping hand on the farm as it is always difficult to cope with cost of hiring labour.

The results also reveal that $31.6 \%$ of the respondents had no formal education, while $68.4 \%$ acquired formal education (primary, secondary and tertiary). The high level of education explains the reason behind easy participation in SFIP in the study area. This corroborates with the findings of Nsoanya and Nenna (2011) that education is an advantage for innovation adoption and transfer. In terms of farming experience, the majority (80.0\%) of the respondents had experience ranging from of $1-20$ years in farming activities. According to Chikezie, Chikaire, Osuagwu, Iheanacho, Ejiogwu-Okereke, Oguegbuchulam and Obi (2012), many years of farming experience will help farmers to make sound decisions as regards resources allocation and management of their farms. Also, the majority (80.6\%) of the respondents had house-hold size ranging from $1-20$ persons with an average of 12 persons per household. Labour usage is mostly both family and hired labour representing $92.8 \%$ while only $7.2 \%$ of the respondents used purely family labour, implying that the respondents have large household size. 
Creative Commons User License: CC BY-NC-ND

Abstracted by: EBSCOhost, Electronic Journals Service (EJS), Google Scholar, Journal Seek, Scientific Commons,

Food and Agricultural Organization (FAO), CABI and Scopus
Journal of Agricultural Extension

Vol. 23 (2) April, 2019

ISSN(e): 24086851; ISSN(Print); 1119944X

http://journal.aesonnigeria.org

http://www.ajol.info/index.php/jae

Email: editorinchief@aesonnigeria.org

Table 1: Socio-economic characteristics

\begin{tabular}{|c|c|c|}
\hline \multirow{2}{*}{\multicolumn{3}{|c|}{$\begin{array}{l}\text { Category } \\
\text { Age (vears) }\end{array}$}} \\
\hline & & \\
\hline$<36$ & 3.3 & 47 \\
\hline $36-45$ & 44.5 & \\
\hline $46-55$ & 28.3 & \\
\hline$>55$ & 23.9 & \\
\hline Total & 100.0 & \\
\hline \multicolumn{3}{|l|}{ Marital status } \\
\hline Married & 94.5 & \\
\hline Widowed & 4.4 & \\
\hline Divorced & 1.1 & \\
\hline Total & 100.0 & \\
\hline \multicolumn{3}{|l|}{ Education } \\
\hline No Formal & 31.6 & \\
\hline Primary & 28.9 & \\
\hline Secondary & 35.6 & \\
\hline Tertiary & 3.9 & \\
\hline Total & 100.0 & \\
\hline \multicolumn{3}{|l|}{ Farming experience } \\
\hline $1-10$ & 55.0 & 10.5 \\
\hline $11-20$ & 25.0 & \\
\hline $21-30$ & 15.0 & \\
\hline$>30$ & 5.0 & \\
\hline Total & 100.0 & \\
\hline \multicolumn{3}{|l|}{ Household size } \\
\hline $1-10$ & 7.8 & 12 \\
\hline $11-20$ & 72.8 & \\
\hline$>20$ & 19.4 & \\
\hline Total & 100.0 & \\
\hline \multicolumn{3}{|l|}{ Labour usage } \\
\hline Family & 7.2 & \\
\hline Both & 92.8 & \\
\hline Total & 100.0 & \\
\hline
\end{tabular}

\section{Source: Field Survey, 2015}

\section{Access to Survival Farming Intervention Programme Activities}

Survival Farming Intervention Programme (SFIP) activities encompasses extension education and training, enhancement of cooperative formation, provision of planting materials and processing equipment, credit provision and others. Table 2 identifies respondents' level of awareness of the programme and participation in some of its activities. The majority $(61.7 \%)$ of the respondents were aware of SFIP, while $38.3 \%$ were not aware which could be due to inadequate dissemination of information about SFIP. Lack of adequate awareness of agricultural intervention programmes usually influences participation in such programmes by the farmers (Edem and Nkereuwen, 2015). Therefore, there is need for proper awareness promotion of agricultural programmes especially SFIP in the study area to enhance massive participation. 
Creative Commons User License: CC BY-NC-ND

Abstracted by: EBSCOhost, Electronic Journals Service (EJS), Google Scholar, Journal Seek, Scientific Commons,

Food and Agricultural Organization (FAO), CABI and Scopus
Journal of Agricultural Extension

Vol. 23 (2) April, 2019

ISSN(e): 24086851; ISSN(Print); 1119944X

http://journal.aesonnigeria.org

http://www.ajol.info/index.php/jae

Email: editorinchief@aesonnigeria.org

More so, about two-third (65.6\%) of the respondents were visited by extension agents under the programme while $34.4 \%$ had no contact with the extension agent which could be due to inadequate personnel to ensure wider coverage. In term of cooperative membership, a majority (73.3\%) were member of cooperative in the study area, while $58.3 \%$ of the respondents had access to credit as introduced under the programme and $41.7 \%$ had no access to credit. Cooperative societies or farmer groups are considered potentially effective mechanisms to increase farmer's productivity and livelihood as production information are easily shared among members. Extension services encompassing training, provision of inputs and credit facilities are mostly extended to farmers through cooperative (Ofuoku and Chukwuji (2012) which is one of the cardinal components of SFIP. Furthermore, the majority $(90.6 \%)$ of the respondents owned their farm land for cassava production implying that participation in SFIP can easily enhance the production capacity of the respondents. Farm land ownership is major criteria for participating in SFIP as it provides opportunities to really benefit from the intervention packages.

Table 2: Accessibility to SFIP activities

\begin{tabular}{lc}
\hline $\begin{array}{l}\text { Category } \\
(\%)\end{array}$ & Percentages \\
\hline Awareness & 38.3 \\
Not Aware & 61.7 \\
Aware & 34.4 \\
Extension visits & 65.6 \\
Not Visited & 26.7 \\
Visited & 73.3 \\
Cooperative & 41.7 \\
Not Member & 58.3 \\
Member & \\
Credit & \\
No Access & \\
Access & 90.6 \\
Land ownership & \\
Not Owned & \\
Owned & \\
\hline
\end{tabular}

\section{Source: Field Survey, 2015}

\section{Constraints Associated with Effective Participation in SFIP}

The constraints faced by the respondents for effective participation in SFIP are presented in Table 3. The majority $(83.9 \%)$ of the respondents identified poor market for produce as one of the major constraints faced by the participants in SFIP and ranked $1^{\text {st }}$ among others. This implies that markets were not readily available for the produce of the respondents in the study area. This finding corroborate that of Agwu, Njom and Umeh (2017) who reported that lack of adequate market to sell produce constitute one of the constraints of participants in their study area. Other major constraints identified include inadequate processing equipment $(82.2 \%)$, lack of adequate information $(81.1 \%)$ and difficulty in accessing credit $(73.3 \%)$ which ranked $2^{\text {nd }}$, $3^{\text {rd }}$ and $4^{\text {th }}$ respectively. Cassava is a perishable produce that cannot be stored in its raw form for more than three days, hence it has to be processed into finished products. Achieving this is always a challenge to rural farmers who used mostly traditional facilities with little or no modern equipment. 
Creative Commons User License: CC BY-NC-ND

Abstracted by: EBSCOhost, Electronic Journals Service (EJS), Google Scholar, Journal Seek, Scientific Commons,

Food and Agricultural Organization (FAO), CABI and Scopus
Journal of Agricultural Extension

Vol. 23 (2) April, 2019

ISSN(e): 24086851; ISSN(Print); 1119944X

http://journal.aesonnigeria.org

http://www.ajol.info/index.php/jae

Email: editorinchief@aesonnigeria.org

http://eoi.citefactor.org/10.11226/v23i2

Credit to acquire the modern equipment are not there as the majority did not have access to credit, while in most cases there is no good markets for the products due to their poor quality.

Table 3: Constraints associated with effective participation in SFIP

Constraints
Ranking

Poor market for produce

83.9

$1^{\text {st }}$

Inadequate processing equipment

82.2

$2^{\text {nd }}$

Lack of adequate information about SFIP

81.1

$3^{\text {rd }}$

Difficulty in accessing credit

73.3

$4^{\text {th }}$

Problem of transportation

67.8

$5^{\text {th }}$

Problem of storage facilities

50.0

$6^{\text {th }}$

Inadequate planting material

49.4

$7^{\text {th }}$

Inadequate extension contact and training

39.4

$8^{\text {th }}$

\section{Source: Field Survey, 2015. *Multiple Response}

\section{Factors Influencing Participation in SFIP}

The result of the Logit regression in Table 4 shows pseudo- $\mathrm{R}^{2}$ of 0.67969 implying that about $68 \%$ of the variation in the participation of SFIP is explained by the independent variables in the Logit regression model. From the $t-$ value of the Logit regression analysis, nine independent variables (age, marital status, gender, labour, education, land tenure, awareness, extension contact and planting materials) were found to be significant. Gender (-2.3744) and land tenure (-2.5995) were negative and statistically significant at $5 \%$ and $1 \%$ probability level, respectively. This implies that they are inversely related to participation in SFIP. One-unit increase in any of the variables will probably decrease respondents' participation in SFIP. The more there are females in cassava production, probability of participating in agricultural programmes decreases which could be due to poor production capacity of the women. More so, poor land tenure system also decreases the probability of participation in agricultural programme as title for farm land will be in contention. However, age (3.2621), marital status (2.4660), labour (2.8822), education (2.5341), awareness (5.4488), extension contact (2.6206) and planting materials (2.8012) were positive and statistically significant at $5 \%$ and $1 \%$ probability level. This implies that they are directly to participation in SFIP. One-unit increase in any of the variables will probably increase respondents' participation in SFIP. Age is one of the farmers' socio-economic variables that go along with experience, therefore, the higher the age of a farmer, the higher the experience and probability to participate in agricultural programmes. Married people are mostly involved in agricultural programmes because of the benefits they could derived from participation. High level of awareness of agricultural programme, availability of labour and farm inputs particularly planting materials enhances participation in agricultural programmes. Education and extension contact also facilitates participation in agricultural programmes. This corroborates the findings of Nwaobiala (2018) who 
Creative Commons User License: CC BY-NC-ND

Abstracted by: EBSCOhost, Electronic Journals Service (EJS), Google Scholar, Journal Seek, Scientific Commons,

Food and Agricultural Organization (FAO), CABI and Scopus
Journal of Agricultural Extension

Vol. 23 (2) April, 2019

ISSN(e): 24086851; ISSN(Print); 1119944X

http://journal.aesonnigeria.org

http://www.ajol.info/index.php/jae

Email: editorinchief@aesonnigeria.org

http://eoi.citefactor.org/10.11226/v23i2

status, education, awareness and extension contact with adoption of production technologies.

Table 4: Factors influencing participation in SFIP

\begin{tabular}{|c|c|c|c|}
\hline Variables & Coefficients & Standard Error & t-value \\
\hline Constant & -88.615 & 25.482 & $-3.478^{\star \star \star}$ \\
\hline Age & 0.2372 & 0.0727 & $3.262^{* * *}$ \\
\hline Marital status & 3.6228 & 1.4613 & $2.466^{\star \star}$ \\
\hline Gender & -2.7602 & 1.1625 & $-2.374^{\star *}$ \\
\hline Labour & 13.0370 & 4.5235 & $2.882^{\star \star \star}$ \\
\hline Education & 0.1493 & 0.0589 & $2.534^{\star * *}$ \\
\hline Experience & -0.6413 & 0.6080 & $-1.055^{\text {NS }}$ \\
\hline Household & 0.2088 & 0.7171 & $0.291^{\text {NS }}$ \\
\hline Farm-size & -0.0434 & 0.7314 & $-0.593^{\mathrm{NS}}$ \\
\hline Land tenure & -1.6259 & 0.6255 & $-2.599^{* * *}$ \\
\hline Awareness & 3.6699 & 0.6736 & $5.448^{\star \star \star}$ \\
\hline Access to credit & -0.1503 & 0.6079 & $-0.247^{N S}$ \\
\hline Extension visits & 0.3829 & 0.1461 & $2.621^{\star * *}$ \\
\hline Coop. membership & 0.0934 & 0.1210 & $0.772^{\mathrm{NS}}$ \\
\hline Planting materials & 3.3573 & 4.5235 & $2.801^{* * *}$ \\
\hline
\end{tabular}

Pseudo - squared $=0.67969,{ }^{* * *} p<0.01,{ }^{* *} p<0.05$

\section{Conclusion and Recommendations}

The majority of the respondents were aware of SFIP and benefited from its activities. Participation in SFIP was statistically influenced by socio-economic factors such as age, education, household size and others in the study area. Major constraints identified include poor market for produce, inadequate processing equipment, lack of adequate information and difficulty in accessing credit. Therefore, to overcome the problem of inadequate information identified by the respondents, it was recommended that extension agents should intensified effort to widen the scope of contact and use better communication medium. In addition, rural markets should be linked to the urban market to attract good value for cassava products thereby enhancing living standard of the farmers especially those in the rural areas.

\section{References}

Adeniyi, R. O. and Adeyemo, B. A. (2014). A review of trends in import of some selected foods in Nigeria. Natural Resources, 5, $367-374$.

Agwu, A. E. Njom, P. C. and Umeh, B. U. (2017). Farmers' adoption scenarios for the control of cassava mosaic disease under the cassava enterprise development project in Enugu State, Nigeria. Journal of Agricultural Extension, 21 (1): $211-217$.

Ajani, E. N., Mgbenka, R. N. and Onah, O. (2015). Empowerment of youths in rural areas through agricultural programmes: Implication for poverty reduction in Nigeria. International Journal of Research in Agriculture, 2 (2): $34-41$.

Ayoade, A. R., Akintonde, J. O. and Oyelere, G. O. (2012). Factors affecting adoption of appropriate technologies on cassava production in Orire LGA, Oyo State, Nigeria. International Research Journal of Agricultural Science and Soil Science, 2 (3): 89 - 93.

Ayodele, O. S., Obafemi, F. N. and Ebong, F. S. (2013). Challenges facing the achievement of the Nigeria vision. Global Advanced Research Journal of Social Sciences, 27, 143- 157. 
Creative Commons User License: CC BY-NC-ND

Abstracted by: EBSCOhost, Electronic Journals Service (EJS), Google Scholar, Journal Seek, Scientific Commons,

Food and Agricultural Organization (FAO), CABI and Scopus
Journal of Agricultural Extension

Vol. 23 (2) April, 2019

ISSN(e): 24086851; ISSN(Print); 1119944X

http://journal.aesonnigeria.org

http://www.ajol.info/index.php/jae

Email: editorinchief@aesonnigeria.org

http://eoi.citefactor.org/10.11226/v23i2

Chikezie, N. P.; Chikaire, J.; Osuagwu, C. O.; Ihenacho, R. A.; Ejiogu-Okereke, N.; Oguegbuchulam, M. N. and Obi, K.U. (2012). Factors constraining rural youths involvement in cassava production in Onu - Imo Local Government Area of Imo State, Nigeria. Global Advanced Research Journal of Agricultural Science, 1 (8): 223 - 232.

Daneji, M. I. (2011). Agricultural development intervention programmes in Nigeria (1960 to Date): A Review. Savannah Journal of Agriculture, 6 (1): $101-107$.

Edem, I. D. and Nkereuwem, M. E. (2015). Crucial roles of tuber crops and the development activities in the global food system. American Journal of Agricultural Sciences, 2 (2): 42 49.

International Institute of Tropical Agriculture (IITA) (2014). IITA's Impact on Cassava continues to spread. The Bulletin, Issue No 2250, IITA, Ibadan, Nigeria.

Iwuchukwu, J. C. and Igboke, E. M. (2012). Lesson from agricultural policies and programmes in Nigeria. Journal of Law, Policy and Globalization, 5, 11 - 23.

Kogi State Agricultural Development Project (KADP) (2014). Annual Progress Report, Lokoja, Kogi State.

Muhammed, Y. (2015). Impact of Survival Farming Intervention Programme (SFIP) in selected LGAs of Kogi State, Nigeria. An MSc Thesis, Department of Agricultural Economics and Rural Sociology, Ahmadu Bello University, Zaria.

National Population Commission (2006). "Nigeria's National Census" NPC, Abuja.

Nsoanya, L. N. and Nenna, M. G. (2011). Adoption of improved cassava production technologies in Anambra-East Local Government Area of Anambra State, Nigeria. Journal of Research for International Development, 9 (2): 36 - 43.

Nwaobiala, C. U. (2018). Farmers' adoption of cassava agronomic practices and intercrop technologies in Abia and Imo States, Nigeria. Journal of Agricultural Extension, 22 (2): 82 96.

Ofuoku, A. U. \& Chukuji, C. O. (2012). Farmers groups growth trend in Delta State Nigeria. Global Journal of Science Frontier Research-Agriculture and Biology, 12 (3): 61 - 66.

Omorogiuwa, O., Zivkovic, J. and Ademoh, F. (2014). The Role of Agriculture in the Economic Development of Nigeria. Europian Scientific Journal, 10 (4): 133 - 147.

Ugwu, D. S. and Kanu, I. O. (2012). Effects of agricultural reforms on the agricultural sector in Nigeria. Journal of African Studies and Development, 4 (2): 51 - 59. 